\title{
Kurimay, Anita. Queer Budapest, 1873-1961. Chicago: University of Chicago Press, 2020.
}

\section{Reviewed by Rita Béres-Deák, Independent Scholar ritakarhukissa@gmail.com}

Writing queer history is always a challenge, partly because of the scarcity of sources, partly because it is hard to decide what counts as "queer" in societies that did not at all have our present-day Western identity categories, and partly because what one finds is often at odds with our contemporary theories of sexual orientation or gender identity. In Central and Eastern Europe, this problem is even further aggravated by the widespread perception that "homosexuality" (or at least the organization of same-sex-attracted people into a separate subculture or let-alone associations) is a recent phenomenon, potentially imported from the West, but definitely not part of the "traditional" culture of these nations (e.g., Edenborg 2017). Therefore, Anita Kurimay's book is important not only as an amazing critical history of a rich array of sources on same-sex sexuality in Hungary from the late nineteenth century to the decriminalization of homosexuality in 1961, but also as a challenging response to widespread beliefs that often form the basis for attacks against the LGBT+ community in Hungary.

Kurimay uses an astounding variety of resources, from legal documents through journal articles to detective stories, to illustrate the frequently conflictive discourses on same-sex sexuality. One of the central topics in this book is the homosexual registry that originated in the late nineteenth century and whose versions survived up to the fall of the socialist state or even longer; in the documentary film Hot Men, Cold Dictatorships journalist László Láner recalls an incident from the early 1990s of the police bragging about having a list of known homosexuals. This typological registry is a fruitful result of the author's archival research, and she uses it as a leading thread to guide the reader through time and various political systems; at the same time, however, this use/usage also means that we get to see same-sex sexuality mostly from the perspective of the state. By way of offering a counterpart to this perspective, Kurimay also relies on other sources (though, regrettably, less so in discussing the socialist-state period) to give us a more comprehensive picture of queers in Budapest. Using additional materials to those cited above becomes important when dealing with same-sex attracted women, because they were hardly if ever registered; so, for example, relying only on police registry would produce yet another account from which lesbianism is excluded. Kurimay is well-aware of this obstacle and in addition to dedicating a whole chapter to one lesbian scandal in interwar Hungary, she takes a systematic decidedly-feminist stance of discussing the situation of women whenever possible and relevant.

Kurimay's book is organized chronologically. She starts her study in 1873 , the year in which the city was born from the unification of Buda, Pest and Óbuda. The first chapter takes us up to the turn of the century with its discussion of the legal regulation of homosexuality and the birth of the homosexual registry, while also offering comparisons with similar practices in other European metropolises of the time. She also briefly discusses the sex/gender system prevalent in

(cc) BY

ULIS D-Serle
New articles in this journal are licensed under a Creative Commons Attribution 4.0 International License.

This journal is published by the University Library System of the University of Pittsburgh as part of its D-Scribe Digital Publishing Program and is cosponsored by the University of Pittsburgh Press 
Hungary in the late nineteenth century, which explains some of the ways in which same-sex attraction was then perceived. The second chapter shows the same period from another perspective, through the work of two popular journalists, Kornél Tábori and Vladimir Székely, who wrote in several books sensationalist accounts of the Budapest "queer" underworld. It is notable that these accounts show sympathy at least toward certain types of homosexuals, and they reveal the existence of a whole male same-sex-oriented subculture. Exposing the mode or undertone of these texts is no less than groundbreaking, especially with regard to Hungary, as it offers a sharp contrast to the popular perception of this period as repressive. The third chapter, discussing the attitude of the 1919 Hungarian Communist Republic toward homosexuality, is equally pioneering, especially as this period is generally under-researched. Even though there is ample literature on the early Communist Republic's being far more lenient toward homosexuality than its successor socialist state of the late 1940s to the late 1980s, Kurimay is the first to describe such tendencies in Hungary around 1920.

The next two chapters in Kurimay's study, the fourth and the fifth, focus on the interwar period. The first of these discusses the lesbian sex-scandal involving the nationalist writer Cécile Tormay, whose recent rediscovery and veneration by today's Hungarian anti-Semitic far-right gives this chapter an added present-day relevance. The fifth chapter again focuses on the attitude of the police (and the Police, the state) toward homosexuality. Somewhat surprisingly, the fascist dictatorship of the end of the Second World War and the state socialism of the 1950s are also covered in this same chapter, probably because of the dire lack of material on both, and especially on the former. Regrettably, this inclusion of the late and postwar times within a chapter devoted to the interwar period creates an equation or analogy of the pre- and postwar periods (somewhat similar to the argument of right-wing discourses in present-day Hungary) and thus makes it harder to notice the important differences between those two periods. Finally, the book's Epilogue explores the contemporary relevance of Hungarian queer history for both homophobic discourses and those of the LGBT+ movement.

One significant lack in Kurimay's book is its scarcity of references to other historical works about same-sex sexualities in the entire East-Central European region of the period under investigation. Considering the post-1949 period, for example, we have valuable materials in English from Poland (Szulc: Transnational Homosexuals in Communist Poland) and East Germany (McLennan: Love in the Time of Communism). Even materials about Russia go further than the official Soviet attitude cited by Kurimay and include also popular discourses and lived experiences (Healey: Homosexual Desire in Revolutionary Russia. The Regulation of Sexual and Gender Dissent). While at the beginning of the present book Budapest is situated in the context of Europe as a whole and the Austro-Hungarian Monarchy, this contextualization is rather lost toward the end of the book. Similarly, in contrast to the wide range of discourses that are employed in the first chapters, the chapter on state socialism relies exclusively on state discourses, although this is the period from which we also have oral-history sources (documented in the two volumes of: Anna Borgos, Eltitkolt évek [' Secret Years'] 2011; Péter Hanzli et al., Meleg férfiak, hideg diktatúrák ['Hot Men, Cold Dictatorships'], 2015). Arguably, the autobiographical short stories of lesbian writer Erzsébet Galgóczi could also have served as sources for this chapter. By ignoring these lived experiences, Kurimay commits the same mistake of obliterating the power of resistance of these communities of queer subjects that she ascribes to the Hungarian LGBTQ movement of the period of state socialism (235).

On p. 152 of her study Kurimay poses the question of whether queer subjects and stories that have been silenced or which do not neatly fit present-day expectations of historians and 
activists should at all be seen as part of the queer history of a given society. Although this is a question that should be considered separately for each case and its overall context, I tend to agree with Eve Sedgwick that queerness often lies in the silences about it, and therefore its discovery requires reading between the lines. Kurimay has performed this task of reading or deciphering brilliantly in her study of the late nineteenth and early-to-mid twentieth century Budapest, and thus she has made a valuable contribution to understanding non-normative identities in Central and Eastern Europe. 